\title{
PSP3 Program and its Impact in Poverty Alleviation (Using Case Study Approach in Bangsal Village, Mojokerto District)
}

\author{
Elias Tande*, Sanggar Kanto, Edi Susilo \\ Brawijaya University \\ Malang, Indonesia \\ "Corresponding author's email: eliastande.noel [AT] yahoo.com
}

\begin{abstract}
Poverty is a social problem faced by Indonesian people until today. This could be seen from high level poverty in Indonesia which was fluctuating from year to year. One of government program to alleviate poverty was Pemuda Sarjana Penggerak Pembangunan di Pedesaan (PSP3) program. It was a program from Youth and Sport Agency of East Java Province to improve empowerment among youth. Study concerning this program's impact, particularly its social impact, was never conducted before, thus this study aimed to identify, analyze and interpret structures which support implementation of PSP3 program, its supporting and impeding factors also impact resulted of its implementation in an effort to alleviate poverty.

This study was a qualitative descriptive with case study approach using Bangsal village in Bangsal subdistrict, Mojokerto as its study site. Informant selection in this study was using purposive sampling method, in which people was assumed and does have connection related with the study such as PSP3 participants, relevant government institution, also village apparatus and its local people. This was done to obtain valid and objective information or data. Collected data and information was analyzed using Giddens's structuration social theory.
\end{abstract}

Keywords--- Empowerment, Sarjana Penggerak Pembangunan di Pedesaan (PSP3) Program, Poverty, Giddens Structuration

\section{INTRODUCTION}

Poverty issue is one of the most serious issues faced by many developing countries. It was also faced by Indonesia until now. Poverty rate from year to year has quite fluctuating. Our government is very active in poverty alleviation programs whereas it is a great challenge for the government as the mandate recipient of Pancasila and UUD 1945, whereas national constitution has made it compulsory to give protection toward all people in Indonesia and to advance general prosperity in order to create social justice for all Indonesian people. Poverty has been discussed for centuries, and reformation era was no exception to this. Amount of disparity between advanced village and underdeveloped village was mostly due to limited professional human resources availability, unorganized socialeconomy institutions which should take an effective and productive role, and unbalance top-down and bottom-up approaches. Also, it was due to centralized policies while villages condition was plural and diverse, unintegrated and incomprehensive village development, not-on-target activities focus, and more importantly, village development policies has not yet fully emphasized on pro poor, pro job and pro growth.

The reality described above was very alarming, why a village with abundant and highly potential natural resources would experience underdevelopment, while the village has vast area, strategic territory and an enabling condition to create and grow. Given the large amount of human resources in the village, supported by abundant natural resources, it shows that national development basis was initiated in villages. It is very unfortunately if national development was not supported by village development.

\section{LITERATURE REVIEW}

Role of youth in poverty alleviation should be facilitated by many things particularly empowerment. This role has several challenges which was actually blessing in disguise, which demanded competent practitioners in their field to be more intense in their region's poverty alleviation efforts. Youth should be provided with empowerment such as good management to solve problems in poverty alleviation effort of their region, so that its implementation would be more effective and efficient.

As one of the program from Youth and Sports Ministry of youth department, PSP3 program was developed with the objective to accelerate development through pioneering role of youth in many youth activities in the future. This commitment is important as part of effort to reduce high educated human resources bulk in urban areas, so that village 
people (youth) were able to rise and conduct productive activities and eventually villages can become the driver of national economy development to overcome social economy and poverty issues in villages (Kemenpora, 2014: 2).

\section{RESEARCH METHOD}

In order to improve effectiveness and success in line with purpose, approaches done by PSP3 covers 5 program strategies, were:

1. Mapping, it was meant to discover village's people condition and its potential as partner.

2. Capacity building, aimed to developed PSP3 resources potential and partner's people by assistant team.

3. Community empowering, a strategy to empower people in an effort to improve prosperity.

4. Networking, is a strategy aimed to build network with other resources to support program's result and achievement.

5. Social marketing, is a strategy to promote and distribute best practice from PSP3 to common people through electric and printed media.

If we observe closely, there were government programs that were only file projects in nature. It means that after the program was terminated, there was no follow-up and it was limited in the completion of the program itself according to the predetermined period of time. In this study, study site was located in Bangsal village, Mojokerto. Reason behind this decision was because PSP3 program implementation was conducted in Bangsal village. From the data obtained either through secondary or primary data by Bangsal village chief, it is known that Bangsal village is a village that acts as productive center of rambak (beef skin) chips. This chip was well known among people in East Java. From this information, PSP3 program shouldn't be placed in this village since its people would be quite established economically. This condition persuades the author to examine whether this program placement has impact and affect people's lifestyle and not only reviewed from its economy aspect but also its social aspect.

\section{RESULT AND DISCUSSION}

Taking the title "PSP3 Program and Its Impact in Poverty Alleviation using case study approach in Bangsal village, Mojokerto district", author choose to use structuration theory, whether its program implementation could be said successful or not would depend on the program's implementer or agent itself. The whereabouts of this agents was related with the supporting structures. Therefore, social and economy change might occur due to relationship between agent and structure. This also occurs in Bangsal, author would like to observe correlation between agent and structures within social-economy change that bring impact toward improvement of village people prosperity.

Generally, poor people were highlighted by powerlessness/inability:

1. Incapable to fulfill basic needs of life such as things related with food and nutrition, clothes, residence or settlement, education and health or in another word was known as basic need deprivation.

2. Incapable to conduct productive activities (unproductiveness)

3. Incapable to access social and economy resources (inaccessibility)

4. Incapable to determine their own faith and always receive discriminative treatment, harboring fear and anxious, also apathetic and fatalistic (vulnerability)

5. Incapable to free themselves from poor mental and poor culture also always feels that they have low dignity (no freedom for poor).

Poverty was seen as lack of capabilities that is if a person, a family, and the people was unable to fulfill the basic needs in life such as things related with food, clothes, housing, health service, education, clean water and sanitation. This lack of capabilities would be causing low physical and mental capability of a person, a family and the people to live their daily life. Poverty seen from income aspect was an income or expenditure level of a person, a family and the people which below certain measure known as poverty line, particularly caused by low asset ownership such as land, capital and business opportunity. 
Rational concept of this study was given below:

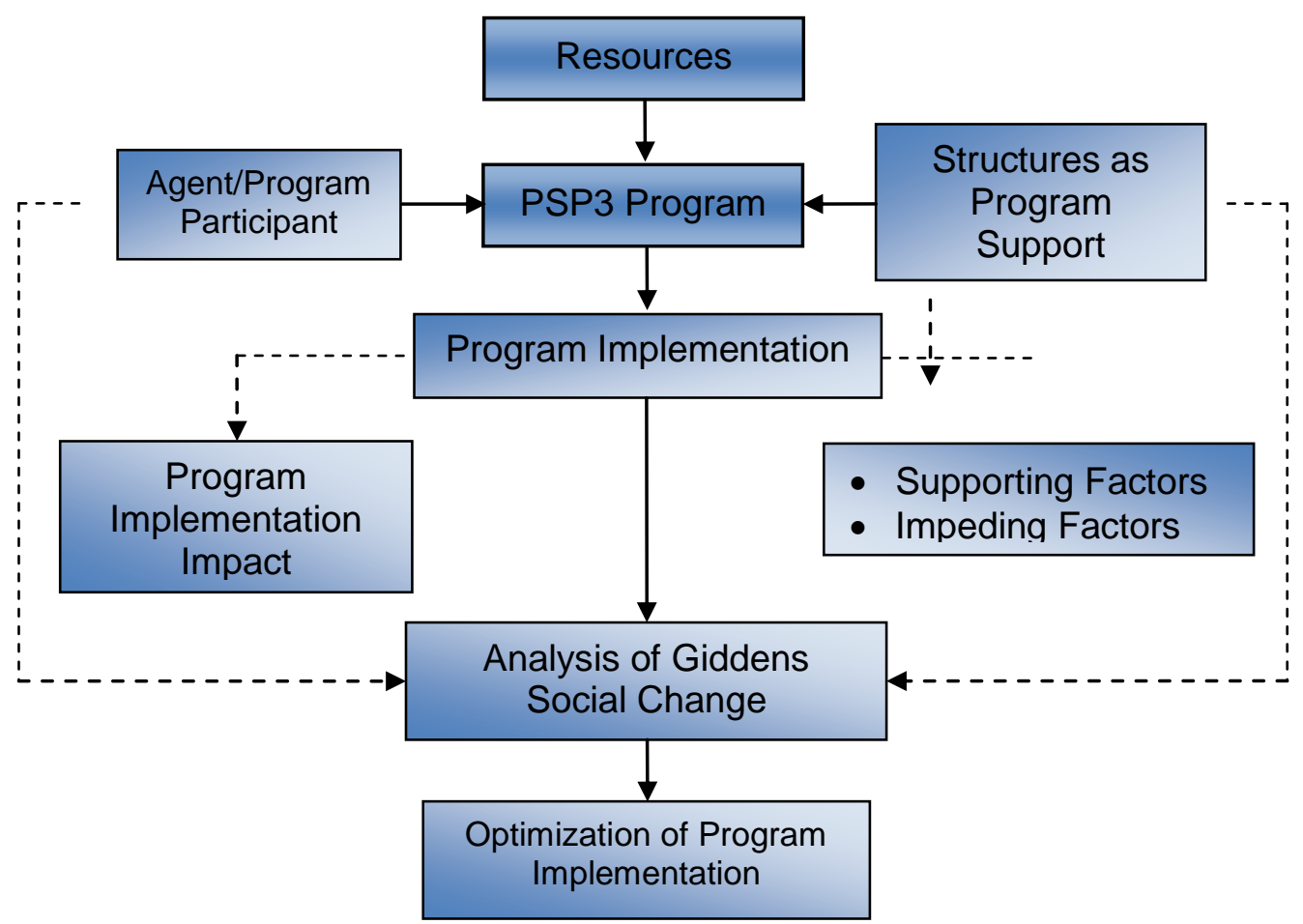

Giddens formulate his structure, system and structuration conceps as follows:

Structure, System and Structuration Concept

\begin{tabular}{|l|l|l|}
\hline \multicolumn{1}{|c|}{ Structure } & \multicolumn{1}{c|}{ System } & \multicolumn{1}{c|}{ Structuration } \\
\hline $\begin{array}{l}\text { Rules and resources or an array } \\
\text { of transformation relations, } \\
\text { organized as complements of } \\
\text { social systems. }\end{array}$ & $\begin{array}{l}\text { Relations reproduced between } \\
\text { actors or collectivities, } \\
\text { organized as social practices. }\end{array}$ & $\begin{array}{l}\text { Conditions which regulate } \\
\text { repeatability or structures } \\
\text { transformation, and thus } \\
\text { reproduction of social systems } \\
\text { itself. }\end{array}$ \\
\hline
\end{tabular}

Source: Anthony Giddens (2010)

Giddens viewed three structure clusters. First of all, marking or signification structure (signification) related with symbolical schematic, meaning, mentioning and discourse. Second, possession or domination structure (domination) which covers possession schematic over people (political) and goods/things (economy). Third, functionalism in discard or ignore space and time aspects when both space and time was basically attached to people or human social practices as actors in social life.

Government has facilitating educated youth potential in villages through Pemuda Sarjana Penggerak Pembangunan di Pedesaan (PSP3) program (Kemenpora, 2013: 10). Through this developmental focus it was expected that PSP3 program could function as education vehicle for educated youth to improve commitment, pioneering spirit, voluntariness and youth awareness toward social economy and poverty issues in the village. The main target of village development was to apply self-support principle and social economy participation in production.

High level of poverty was an irony in itself since this low poverty line occurs in the midst of abundant natural resources in the village. This reality illustrate that government capacity was still inadequate in managing the existing resources and in creating development innovation. Current policies were not effective enough to expand ownership and possession of developmental resources in various groups. The existence of a program within a community should be based on current issues faced by the community itself. In the urgent condition of PSP3 program within the community, it was related with at least three issues: working educated youth, village development, youth and national dynamics.

Study related with PSP3 program in several region showed that this program was highly supported by the people and it can be seen from its continuity between the people and PSP3 participants. Study site discussed in this paper was located in Bangsal village. Bangsal village was one of the villages in Bangsal sub-district with 3.149 villagers and home for $30 \%$ poor households, as showed in data of PPLS 2011. Data obtained from PPLS 2011 showed that there was an increase of poor people. Looking at this condition, related agency or Youth and Sport Agency of Mojokerto District has placed PSP3 program in Bangsal village. 
Development of Bangsal village in the last couple of years has met stagnancy whereas most of its villagers would depend on agricultural sector and processing of krupuk rambak (beef skin chips). This was stated by Bangsal village chief. With PSP3 program, it was expected that this program would be able to give ideas and concepts concerning how to empower the existing resources potential. Based on data obtained from Pemberdayaan Masyarakat Desa Kabupaten Mojokerto 2014, productive-age villagers that have no employment in Bangsal village were 504 men and 336 women from total 3.149 people in Bangsal village. From this number, there was $27 \%$ productive-age villager that has no employment. With PSP3 program, it was expected to open new employment and thus reduce unemployment rate.

This study was a qualitative descriptive study using case study approach. Informant selection was using purposive sampling, in which people was assumed and does have connection related with the study such as PSP3 participants, relevant government institution, also village apparatus and its local people. This was done to obtain valid and objective information or data. Data collection technique used in this study was field observation, interview with structured and unstructured interview techniques, and documentation. Collected data and information was analyzed using Giddens's structuration social theory.

\section{CONCLUSION}

From this study, it can be concluded that structures which support program implementation and activities of PSP3 program in this study site were all villagers, Bangsal village apparatus and Bangsal village environmental condition. It was also known that supporting factors of PSP3 program implementation were bureaucracy structures, resources, communication and participant's character, also its impeding factors of PSP3 implementation were capital, participant's knowledge, and low number of participant in placement location, also impact caused by PSP3 program in an effort to alleviate poverty were social change among the people in the form of improvement in people's awareness of their own environment and improvement in community empowerment in this program placement site.

Recommendation given in this study was that assistance team should has appropriate knowledge with PSP3 participant's knowledge, thus they could give advice for each issues emerged on the field. As government attention toward PSP3 program, through Youth and Sport Ministry, they should give appreciation toward best participant of every class not just a certificate and money for management, but they should give other appreciation such as permanent employment as government employees (civil servant). This appreciation would stimulate PSP3 participant's spirit in completing their tasks.

\section{SUGGESTION}

Overcoming poverty issues should be done gradually, ongoing and integrated. According to Giddens (Maufur and Daryanto, 2010: 25), core of structuration theory lies in its three main concepts which were related with "structure", "system" and "structure duality", particularly in its relationship between agents (actors) and structure. Giddens with his structuration theory emphasize review of "current social practice" as he said that "basic domain of social sciences, according to structuration theory, was not individual actor's experience, or existence of any social totality, but ordered practices along space and time."

Structuration theory was based on view regarding structures. However, Giddens' concept or view regarding structures was different from structuralism or post-structuralism view, although until certain limit, Giddens' concept regarding structure was not easy to comprehend and was likely to invite critics.

In Giddens view, structure acts as "rules and resources", which always being produce and reproduce, also has duality relationship with the agency, and create various social practice. Giddens critic toward structuralism was that structuralism view, particularly functional-structuralism, tends to focus on "function" and not "structure" and therefore put structure as something on the outer layer.

\section{REFERENCES}

1. Basrowi dan Sujarwo, 2009. Manajemen Penelitian Sosial. CV. Mandar Maju. Bandung.

2. Bayoala, Andre. 1981. Kemiskinan dan strategi memerangi kemiskinan. Cetakan Pertama. Liberty. Yogyakarta.

3. Blaxter, Loraine.,Hughes C. and Thight Malcolm. 2006. How to research, seluk beluk melakukan riset. Edisi Kedua. Indeks Kelompok Gramedia. Jakarta.

4. Giddens, Anthony. 1993. Sociology. Second Edition. Cambridge-UK: Polity Press..

5. Giddens, Anthony. Teori Strkturasi: Dasar-dasar Pembentukan Struktur Sosial Masyarakat, terjemahan Maufur \& Daryanto. Yogyakarta: Pustaka Pelajar. 2010.

6. Hanafi, Abdillah. 1986. Memasyarakatkan ide-ide baru. Cetakan Ketiga. Usaha Nasional. Surabaya.

7. Idrus, Muhammad. 2009. Metode penelitian ilmu sosial. Edisi Kedua. Erlangga. Yogyakarta.

8. Kanto, Sanggar. 2011. Perspektif modernisasi dan perubahan sosial. Edisi Pertama. UB Press. Malang.

9. Susilo, Edi. 2010. Dinamika, struktur sosial dalam ekosistem pesisir. Cetakan Pertama. UB Press. Malang. 
10. Kemenpora, 2013. Pedoman umum pelaksanaan program pemuda sarjana penggerak pembangunan di perdesaan (PSP3), Jakarta.

11. Soenyono, 2012. Sosiologi pemberdayaan masyarakat (community, empowerment). Cetakan Pertama. Jenggala Pustaka Utama. Surabaya

12. K.Yin, Robert. 2013. Studi kasus. Cetakan ke-12. Raja Grafindo Persada. Jakarta

13. Moleong, Lexy. J. 2012. Metodologi penelitian kualitatif. Edisi Revisi. Remaja Rosdakarya. Bandung. 